\title{
Global vaccine project gets a shot in the arm
}

\section{Erika Check, Washington}

Two donors this week gave US $\$ 1$ billion to a project that immunizes children in the world's poorest countries against preventable diseases such as hepatitis B and yellow fever.

On 24 January, the Seattle-based Bill and Melinda Gates Foundation and the Norwegian government announced ten-year grants of $\$ 750$ million and $\$ 290$ million, respectively, to the Global Alliance for Vaccines and Immunization (GAVI).

That is a big sum, but, to put it in context, a further $\$ 8-10$ billion will be needed over the next ten years just to get existing vaccines out to the children who need them, according to the World Health Organization (WHO). And that is before counting the extra costs of delivering new vaccines, such as shots against rotavirus and pneumococcus, as these come on to the market.

The sum of $\$ 10$ billion is not much more than the international community has pledged to tsunami relief in three weeks. However, "the tsunami was a very visible demonstration of need in developing countries", says David Fleming, director of global health strategies for the Gates foundation. "The issue with immunization is that millions of children are dying needlessly, but because deaths do not occur in a single disaster, it is harder to attract the attention of donors."

Geneva-based GAVI, whose partners include the United Nations' children's fund, the WHO, governments and commercial vaccine-makers, was created in 1999 with $\$ 750$ million of Gates funding, and other donors have since brought its total funding to $\$ 1.3$ billion. "We think this is the best investment we've ever made," said Bill Gates in a teleconference with reporters, pointing

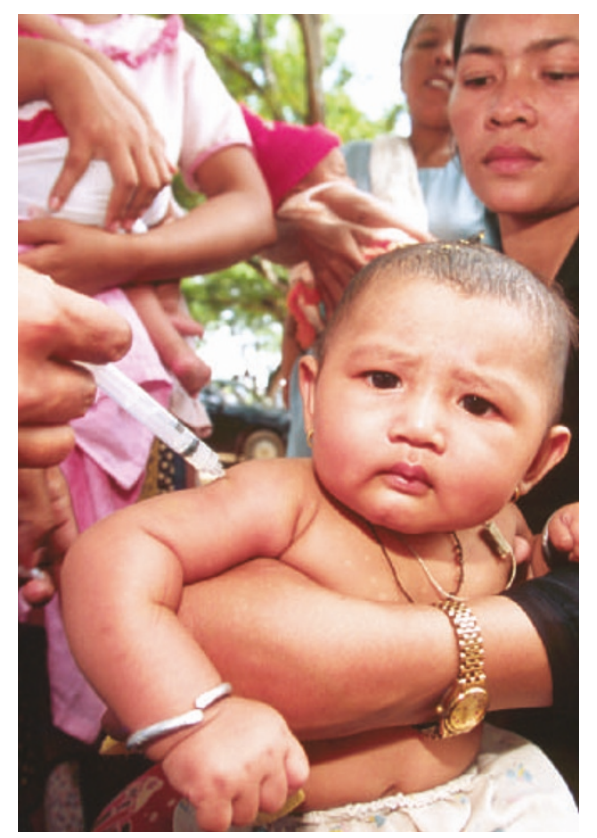

Booster shot: billions of dollars are still needed to get jabs to children in poorer countries.

out that GAVI programmes have prevented the deaths of 670,000 children born between 2001 and 2003 in 71 countries.

"We boosted routine immunization coverage for diphtheria, tetanus and whooping cough from $53 \%$ in 2000 to $81 \%$ in 2003 ," said Yoweri Museveni, president of Uganda, in a statement. "And because GAVI has a unique incentive system, our funding actually increased when we reached our immunization targets."

As well as delivering vaccines, the large sums involved are indirectly encouraging more vaccine research, says Julian Lob-Levyt, executive secretary of GAVI. "Assurance of markets over the long-term encourages industry to invest greater resources in research and development for urgently needed vaccines, such as those for malaria."

But much remains to be done. In 2002, 1.4 million children under five years of age died from vaccine-preventable diseases. In 2003, more than 27 million children went without vaccinations in their first year of life. Attacking this problem is key to reducing child mortality - one of the UN Millennium Development Goals, a series of commitments signed by all UN members in 2000 . The target is to reduce the under-five mortality rate by two-thirds between 1990 and 2015, but so far the world looks as if it will need an extra two decades to achieve this.

Global health is on the agenda at the annual meeting of the World Economic Forum being held this week in Davos, Switzerland. Gates will take his place on a panel with Tony Blair, the UK prime minister, and the outspoken rock star Bono. Blair's government is pushing for an International Finance Facility that would raise $\$ 50$ billion a year in development aid between now and 2015: the facility would sell bonds on capital markets that would be recovered by donor funds pledged over several decades. Gates says he is very excited about this approach.

"Modest amounts of resources can save large numbers of lives," says Gates, regretting that making global health an international spending priority is "very, very difficult".

"When people see tsunami victims on the TV, they do want to reach out; they do want to provide resources and help," he adds. "We all need to think creatively about how we can tap into the human compassion that's there."

\section{MIT wraps up Dublin lab following funding failure}

Roxanne Khamsi, London

Media Lab Europe, the European arm of the world-famous Media Lab at the Massachusetts Institute of Technology (MIT) in Cambridge, is to close next week, less than five years after it opened.

The research lab, based in Dublin, was launched in $\mathbf{2 0 0 0}$ during the dotcom bubble. It was a joint venture between MIT and the Irish government, which invested $€ 35$ million (US\$46 million) in the centre. The original plan was that corporate sponsors would supplement the cost of running the lab, which has some 60 staff, including around 40 scientists. But in 2003 the lab spent more than $€ 8$ million and raised only $€ 2.6$ million. Overall, it managed to hook just eight partners. "It was difficult to attract the



corporate funding we had hoped for," says Sorcha Duggan, a spokeswoman for the lab. In 2004, the lab asked the government to fund its next three years with a $€ 9$-million grant, but the request was refused.

The stock-market bubble burst in 2000, slashing the share value of potential sponsors. Observers also argue that the lab's research, which included projects on "the future of human relationships as mediated by technology", was too abstract to attract investment, especially in Europe, which has less of a culture of corporate sponsorship than the United States.

"It's a bit of a blow," says Seán Duke, editor of Technology Ireland. He points out that Ireland has taken pride in its ability to attract foreign high-tech investment.

MIT pulled out of its Media Lab Asia in New Delhi in 2003. This followed a row with the Indian government, which wanted the futuristic centre to focus on more practical goals (see Nature 423, 213; 2003). The latest closure leaves Media Lab with no links to spin-offs outside the United States. 